\title{
Evaluation of the Effect of Irrigation and Fertilization by Drip Fertigation on Tomato Yield and Water Use Efficiency in Greenhouse
}

\author{
Wang Xiukang ${ }^{1}$ and Xing Yingying ${ }^{1,2}$ \\ ${ }^{1}$ College of Life Science, Yanian University, Yanian, Shaanxi 716000, China \\ ${ }^{2}$ Key Laboratory of Agricultural Soil and Water Engineering in Arid and Semiarid Areas of Ministry of Education, \\ Northwest A\&F University, Yangling, Shaanxi 712100, China
}

Correspondence should be addressed to Wang Xiukang; wangxiukang@126.com

Received 30 January 2016; Revised 11 June 2016; Accepted 14 June 2016

Academic Editor: Othmane Merah

Copyright @ 2016 W. Xiukang and X. Yingying. This is an open access article distributed under the Creative Commons Attribution License, which permits unrestricted use, distribution, and reproduction in any medium, provided the original work is properly cited.

\begin{abstract}
The water shortage in China, particularly in Northwest China, is very serious. There is, therefore, great potential for improving the water use efficiency (WUE) in agriculture, particularly in areas where the need for water is greatest. A two-season (2012 and 2013) study evaluated the effects of irrigation and fertilizer rate on tomato (Lycopersicum esculentum Mill., cv. "Jinpeng 10") growth, yield, and WUE. The fertilizer treatment significantly influenced plant height and stem diameter at 23 and 20 days after transplanting in 2012 and 2013, respectively. As individual factors, irrigation and fertilizer significantly affected the leaf expansion rate, but irrigation $\times$ fertilizer had no statistically significant effect on the leaf growth rate at 23 days after transplanting in 2012 . Dry biomass accumulation was significantly influenced by fertilizer in both years, but there was no significant difference in irrigation treatment in 2012. Our study showed that an increased irrigation level increased the fruit yield of tomatoes and decreased the WUE. The fruit yield and WUE increased with the increased fertilizer rate. WUE was more sensitive to irrigation than to fertilization. An irrigation amount of 151 to $208 \mathrm{~mm}$ and a fertilizer amount of 454 to $461 \mathrm{~kg} \cdot \mathrm{ha}^{-1}$ (nitrogen fertilizer, $213.5-217 \mathrm{~kg} \cdot \mathrm{ha}^{-1}$; phosphate fertilizer, $106.7-108 \mathrm{~kg} \cdot \mathrm{ha}^{-1}$; and potassium fertilizer, $133.4-135.6 \mathrm{~kg} \cdot \mathrm{ha}^{-1}$ ) were recommended for the drip fertigation of tomatoes in greenhouse.
\end{abstract}

\section{Introduction}

Technologies such as drip irrigation and fertigation can improve WUE and decrease salinization while maintaining or increasing yields [1]. Fertigation is an agricultural water management technology that supplies water and fertilizer simultaneously in a drip irrigation system, feeding a crop by injecting soluble fertilizers into water and then transporting them into the root zone [2]. Fertigation, which can improve the efficiency of irrigation water and fertilizer, is a new fertilization method of precision agriculture [3]. In the late 1970s, the use of fertigation technology was widespread in China, particularly in the North and Northwest regions, where water shortage is very serious [4]. In drip fertigation systems, which combine drip irrigation with fertilizer application, the fruit yield of tomato was $20-30 \%$ higher in drip fertigation than in furrow irrigation [5]. It is well known that water and fertilizer are the two main factors limiting vegetable and crop production in arid and semiarid regions [6-8].

Tomato is one of the most popular and widely grown vegetables in the world. The first reason for this is that tomatoes are beneficial to our heath and are good sources of provitamins, $\beta$ carotene, and vitamin $\mathrm{C}$. The second reason is that tomatoes are particularly rich sources of lycopene, which is a very powerful antioxidant and helps prevent the development of many forms of cancer [9-12]. Hence, this vegetable is gaining importance in both developing and developed countries, and efforts are being made to improve the quality and quantity of tomato production [13-15]. Of course, water supply is important for tomato yield quantity and quality. Increasing the water supply increases fruit yield but significantly reduces the brix, lycopene, and total polyphenol contents of fruits; the 


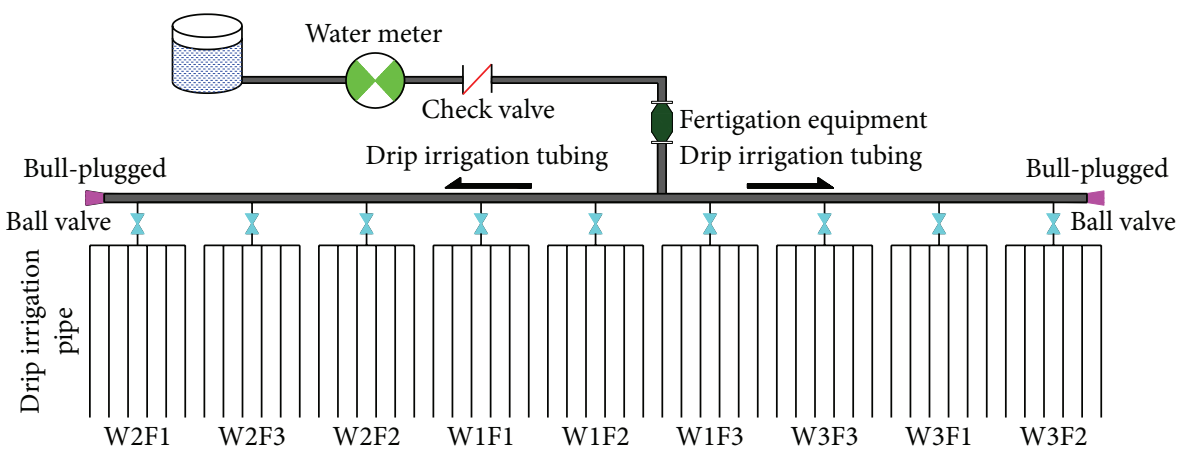

FIGURE 1: The layout of experiment included water sources, water meter, check valve, fertigation equipment, and ball valve and drip irrigation pipe positions of different treatments in greenhouse.

ascorbic acid content is significantly higher under optimum water supply conditions [16-18]. Water stress is one of the most important environmental factors that regulate plant growth and development and limit plant production [19].

Tomato responds well to fertilizer application and is reported to be a heavy feeder of nitrogen $(\mathrm{N})$, phosphorus $(\mathrm{P})$, and potassium $(\mathrm{K})$ fertilizer [5]. It is partially compatible with drip irrigation, which is a very efficient use of water and nutrients $[20,21]$. Previous studies have suggested that the $\mathrm{N}$ use efficiency and $\mathrm{N}$ agronomic efficiency decreased with increases in fertilizer $\mathrm{N}$ rate and that the $\mathrm{N}$ rate of $271 \mathrm{~kg} \cdot \mathrm{ha}^{-1}$ produced the highest marketable yield and $265 \mathrm{~kg} \cdot \mathrm{ha}^{-1}$ produced the optimum economic yield $[22,23]$. Nitrogen, phosphorus, and potassium are essential for tomato production [24], and the recommended balanced rates of fertilization include twice as much $\mathrm{N}$ as $\mathrm{P}$ and $\mathrm{K}$ [25]. According to the literature, the application of deficit irrigation at the seedling stage may not significantly influence the total yield of greenhouse tomato [26]. The excessive use of irrigation water leads to low water productivity and deterioration [27]. To maximize tomato water productivity, priority must be given to the efficient use of water, both to improve yields and to control water use by minimizing nonbeneficial water use [28].

Therefore, the development of efficient agricultural water use is not only necessary but also feasible, being critical to improve the fruit yield and WUE. To obtain high yields and maximum profits in commercial tomato production, the optimal management of both fertilizer and water is required. Previous studies have focused on the influence of irrigation amount and fertilizer rate on tomato growth, fruit yield, and quality. Meanwhile, it is necessary to select an optimal combination of irrigation and fertilization to improve agricultural water and fertilizer management practices. Therefore, the aim of this study is to explore the effect of irrigation and fertilization on the growth, yield, and quality of tomato with fertigation by drip irrigation and to make recommendations regarding the strategies for growing greenhouse tomatoes.

\section{Materials and Methods}

2.1. Experimental Site and Treatments. The tomatoes plant (Lycopersicum esculentum Mill., cv. "Jinpeng 10") was used for our experiment in the greenhouse, located at the Key Laboratory of Agricultural Soil and Water Conservation Engineering in Arid Areas $\left(34^{\circ} 20^{\prime} \mathrm{N}, 108^{\circ} 04^{\prime} \mathrm{E}\right.$, and altitude $521 \mathrm{~m}$ ), Shaanxi Province, China. The topsoil $(0-80 \mathrm{~cm})$ has a bulk density of $1.42 \mathrm{~g} \cdot \mathrm{cm}^{-3}$, a $\mathrm{pH}$ of 8.12 , and a field capacity of $25 \% \mathrm{~cm}^{3} \cdot \mathrm{cm}^{-3}$, an organic matter content of $13.8 \mathrm{~g} \cdot \mathrm{kg}^{-1}$, a total nitrogen content of $0.82 \mathrm{~g} \cdot \mathrm{kg}^{-1}$, an available phosphorus content of $13.2 \mathrm{~g} \cdot \mathrm{kg}^{-1}$, an available potassium content of $105.8 \mathrm{~g} \cdot \mathrm{kg}^{-1}$, and an available nitrogen content of $74.12 \mathrm{mg} \cdot \mathrm{kg}^{-1}$.

In this experiment, nine treatments were designed with three different irrigation levels (W1: $100 \% \mathrm{ET}_{c} ; \mathrm{W} 2: 75 \% \mathrm{ET}_{c}$; W3: $50 \% \mathrm{ET}_{c}$ ) and fertilizer levels (F1: N240- $\mathrm{P}_{2} \mathrm{O}_{5} 120-$ $\mathrm{K}_{2} \mathrm{O} 150 \mathrm{~kg} \cdot \mathrm{ha}^{-1}$; F2: N180- $\mathrm{P}_{2} \mathrm{O}_{5} 90-\mathrm{K}_{2} \mathrm{O} 112.5 \mathrm{~kg} \cdot \mathrm{ha}^{-1}$; F3: $\mathrm{N} 120-\mathrm{P}_{2} \mathrm{O}_{5} 60-\mathrm{K}_{2} \mathrm{O} 75 \mathrm{~kg} \cdot \mathrm{ha}^{-1}$ ). The experiment was organized using a randomized block design with three replications; each plot was $6 \mathrm{~m}$ long, $1.25 \mathrm{~m}$ wide, and $22.5(3 \times 6 \times 1.25=$ 22.5) $\mathrm{m}^{2}$ in area. Total 9 divided and ridged experimental plots were divided by a water barrier sheet. A mosaic column emitter type drip irrigation tape (Hebei Green Water Conservancy Engineering Co., Ltd., Shijiazhuang, Hebei Province, China) was used in this experimental irrigation system, with an external diameter of $16 \mathrm{~mm}$, drip tape emitter spacing of $30 \mathrm{~cm}$, a head flow of $2 \mathrm{~L} \mathrm{~h}^{-1}$, and a drip irrigation operating pressure of $0.3 \mathrm{MPa}$ (Figure 1).

2.2. Crop Management, Harvesting, and Measurements. The tomato seedlings were transplanted on 21 Mar 2012 and 31 Mar 2013. The furrow-film mulch was cultivated by the local traditional planting patterns and calendars using tomato ridging in a tube with a two-line spaced layout; the tubes were placed $50 \mathrm{~cm}$ apart, with a $45 \mathrm{~cm}$ planting distance and 78 plants in each experimental plot. Drip fertigation was performed using a fertilizer of urea $(46 \% \mathrm{~N})$, diammonium phosphate $\left(44 \% \mathrm{P}_{2} \mathrm{O}_{5}\right)$, and potassium chloride $\left(60 \% \mathrm{~K}_{2} \mathrm{O}\right)$. This fertilizer was applied five times at the recovering stage, the blossoming and bearing fruits stage, the first fruit enlargement period, the second fruit enlargement period, and the third fruit enlargement period, and the fertilization ratio was $1: 1: 2: 2: 2$ for those applications.

The plant height in each treatment was measured every 15 to 20 days after transplanting. The height of 3 randomly 
selected plants from each experimental unit was measured three times per month from the soil level to the growing point.

Changes in stem diameter were continuously recorded during the treatment period using a shrinkage-type microdisplacement detector (Portable Battery Internal Resistance Tester, JZ-1A, Peking, 2010). All of the measurements were recorded three times and the pattern of response was similar in all.

The number of leaves longer than $20 \mathrm{~mm}$ was determined once every 2 weeks, and the maximal leaf width was measured for every leaf. The leaf area was estimated by multiplying the product of leaf length and leaf width by a conversion factor estimated from the destructive sampling.

Plants were harvested in three replicates and separated into roots, leaves, fruits, and stem. The plant parts were dried in an open-air draught oven at $75^{\circ} \mathrm{C}$ for $72 \mathrm{~h}$ to estimate the dry weight.

Ripe tomatoes were harvested and fresh total yield and total number of tomatoes from all of the plants in each plot were determined. The fruit yield was measured throughout the crop. Fruits were harvested twice a week for a period of 9 weeks and were separated into marketable and total yields.

2.3. Irrigation Management. Irrigation treatments were initiated using the surface drip irrigation system during transplanting, and the irrigation amount was $40 \mathrm{~mm}$. Irrigation was applied using a subsurface drip system based on the daily crop evapotranspiration $\left(\mathrm{ET}_{c}\right)$, which was calculated as a product of the reference evapotranspiration $\left(\mathrm{ET}_{0}\right)$ and the stage-specific crop coefficients $\left(K_{c}\right)$.

The FAO 56 Penman-Monteith method is recommended as the standard method for $\mathrm{ET}_{0}$ estimation [29, 30]. Fernández et al. reported the FAO 56 Penman-Monteith equation with a fixed aerodynamic resistance of $295 \mathrm{~s} \mathrm{~m}^{-1} \mathrm{can}$ better estimate daily $\mathrm{ET}_{0}$ in greenhouse [31]:

$$
\mathrm{ET}_{0}=\frac{0.48 \Delta\left(R_{n}-G\right)+\gamma(628 /(T+273))\left(e_{s}-e_{a}\right)}{\Delta+628 \gamma},
$$

where $R_{n}$ is the net radiation $\left(\mathrm{MJ} \mathrm{m}^{-2} \mathrm{~d}^{-1}\right), G$ is the soil heat flux $\left(\mathrm{MJ} \mathrm{m}^{-2} \mathrm{~d}^{-1}\right), \Delta$ is the slope of the saturated vapour pressure curve $\left(\mathrm{kPa}^{\circ} \mathrm{C}^{-1}\right), \gamma$ is the psychometric constant $\left(\mathrm{kPa}^{\circ} \mathrm{C}^{-1}\right), e_{s}$ is saturation vapour pressure $(\mathrm{kPa}), e_{a}$ is actual vapour pressure $(\mathrm{kPa})$, and $e_{s}-e_{a}(\mathrm{VPD})$ is the vapour pressure deficit $(\mathrm{kPa})$. The calculation procedures of parameters $R_{n}, G, e_{s}, e_{a}, \Delta, \gamma$, and $T$ were described in FAO $56[31,32]$. The average daily environmental condition at different growth stages of tomato inside the greenhouse and the seasonal variation of daily $\mathrm{ET}_{0}$ are calculated using (1) (Figure 2).

The $K_{c}$ values were as follows: $K_{c \text { ini }}=0.5, K_{c \text { mid }}=0.85$, and $K_{c \text { end }}=0.6$ [32]. The irrigation amounts of the W1, W2, and W3 treatments were, respectively, 262.00, 206.50, and $151.00 \mathrm{~mm}$ in 2012 and 279.80, 219.85, and $159.85 \mathrm{~mm}$ in 2013. The irrigation frequency and total amount of water applied during the full irrigation treatment are given in Figure 3.

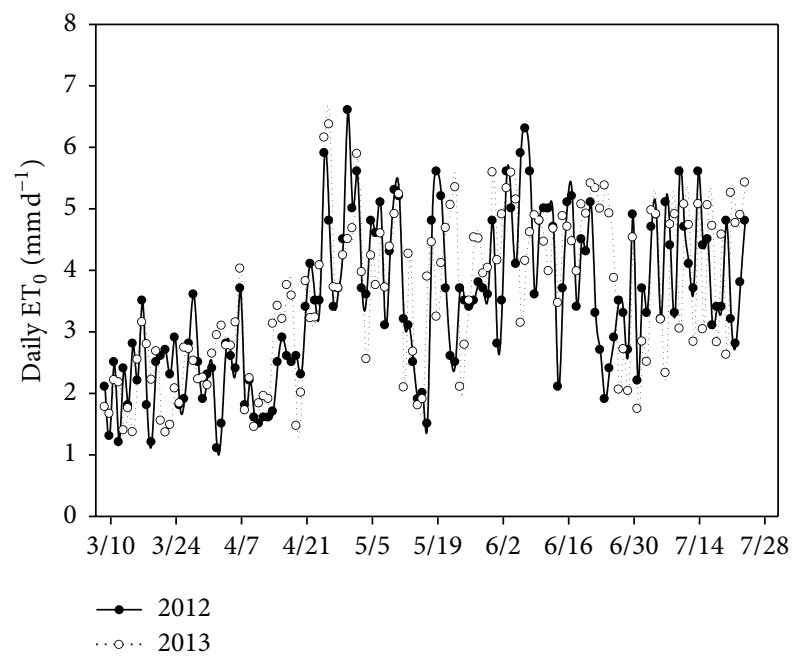

FIGURE 2: Daily variation of the reference evapotranspiration $\left(\mathrm{ET}_{0}\right)$ against days for the tomatoes growing seasons of 2012 and 2013.

The water use efficiency (WUE) was determined using the following equation $[33,34]$ :

$$
\mathrm{WUE}=\frac{Y}{\mathrm{ET}_{c}} \times 100,
$$

where WUE is measured in $\mathrm{kg} \cdot \mathrm{m}^{-3}, Y$ is the total fruit yield $\left(\mathrm{t} \cdot \mathrm{ha}^{-1}\right)$, and $\mathrm{ET}_{c}$ is the crop water consumption $(\mathrm{mm})$.

2.4. Statistical Analysis. Analysis of variance was conducted on the plant height, stem diameter, dry biomass accumulation, and distribution in different organs using a two-way analysis of variance (SAS GLM procedure version 9.2, SAS Institute Ltd., North Carolina, USA). Duncan's multiple range tests were considered significant when $p<0.05$.

\section{Results}

3.1. Plant Height, Stem Diameter, and Leaf Growth Rate. The effects of irrigation amount and fertilizer rate on plant height at the whole growth stages are shown in Table 1. In 2012, the results show that the single factors of irrigation amount or fertilizer application rate very significantly affected plant height at 23 days after transplanting, and the interaction between irrigation and fertilization had an obvious effect. The highest plant height was $40.8 \mathrm{~cm}$ in the W2F1 treatment, which was significantly higher than that of the other plants. At 37 days after transplanting, the average added values of plant height in W3 $(40.8 \mathrm{~cm})$ were $6.9 \%$ and $10.3 \%$ higher than those in the W1 and W2 treatments in 2012. During the recovering stage, the rate of plant height increase was faster, and, with the advancement of the blossoming and bearing fruits stage, the rate of increase decreased by 53 days after transplanting. The average plant height in W3 was higher than that in the W1 treatment, but there was no significant plant height difference among the irrigation treatments 70 days after transplanting. In addition, irrigation $\times$ fertilizer had no statistically significant effect on plant height. 

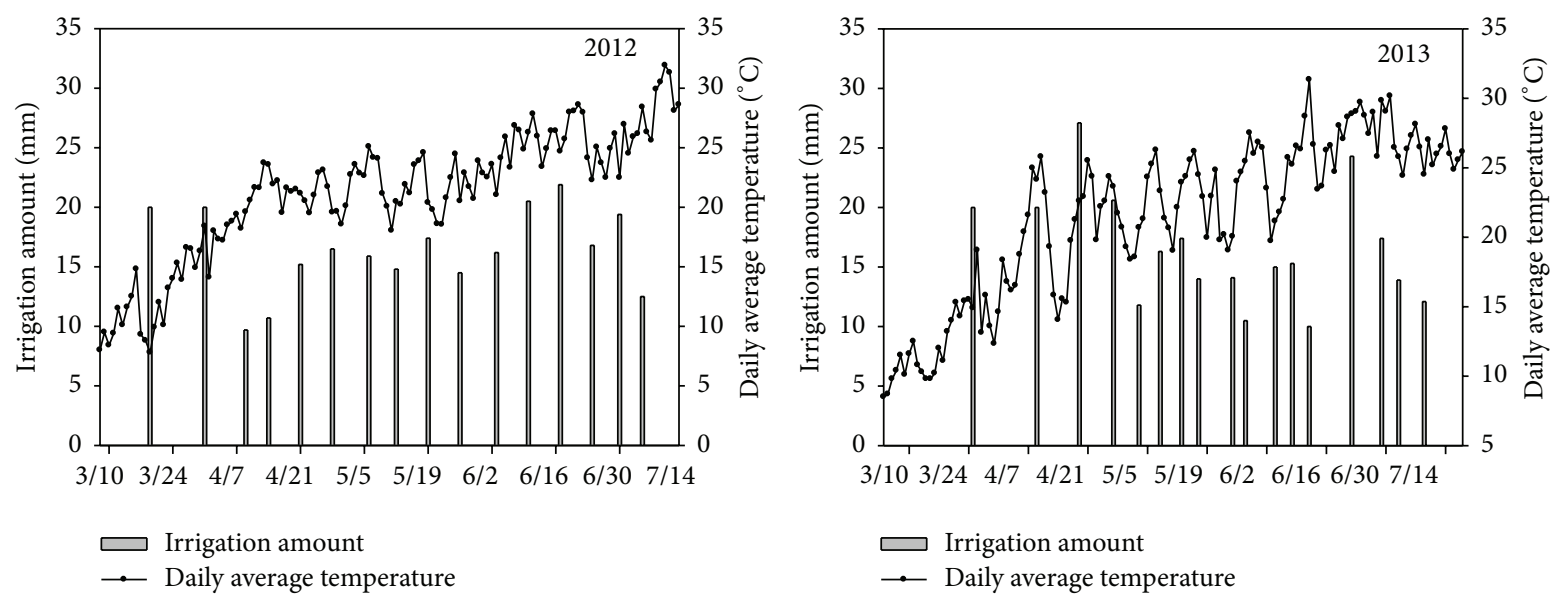

FIGURE 3: In tomato growing season, the distribution of daily average temperature, irrigation interval, and numbers were recorded in the study years.

TABLE 1: The effects of irrigation amount and fertilizer rate on plant height of tomato $(\mathrm{cm})$.

\begin{tabular}{|c|c|c|c|c|c|c|c|c|}
\hline \multirow{2}{*}{ Treatments } & \multicolumn{4}{|c|}{2012} & \multicolumn{4}{|c|}{2013} \\
\hline & $23 \mathrm{D}$ & $37 \mathrm{D}$ & $53 \mathrm{D}$ & $70 \mathrm{D}$ & $20 \mathrm{D}$ & $40 \mathrm{D}$ & $60 \mathrm{D}$ & $80 \mathrm{D}$ \\
\hline W1F1 & $35^{\mathrm{cd}}$ & $71.2^{\mathrm{cd}}$ & $102^{\mathrm{d}}$ & $125.8^{\mathrm{b}}$ & $23.9^{b c}$ & $70.9^{\mathrm{ab}}$ & $93.9^{\mathrm{bcd}}$ & $112.5^{\mathrm{ab}}$ \\
\hline $\mathrm{W} 1 \mathrm{~F} 2$ & $35.7^{\mathrm{cd}}$ & $72.5^{\mathrm{bcd}}$ & $109^{a b c}$ & $134.1^{\mathrm{ab}}$ & $24.1^{\mathrm{bc}}$ & $68.6^{\mathrm{abc}}$ & $101.5^{\mathrm{a}}$ & $117.4^{\mathrm{a}}$ \\
\hline W1F3 & $34.3^{\mathrm{d}}$ & $70.3^{\mathrm{cd}}$ & $105^{\mathrm{bcd}}$ & $130^{\mathrm{ab}}$ & $23.2^{\mathrm{bc}}$ & $67.8^{\mathrm{abc}}$ & $88^{\text {cde }}$ & $112^{\mathrm{ab}}$ \\
\hline $\mathrm{W} 2 \mathrm{~F} 1$ & $40.8^{\mathrm{a}}$ & $76.5^{\mathrm{ab}}$ & $110.5^{\mathrm{ab}}$ & $140.3^{\mathrm{a}}$ & $29.7^{\mathrm{a}}$ & $68.4^{\mathrm{abc}}$ & $94.1^{\mathrm{bcd}}$ & $111.5^{\mathrm{ab}}$ \\
\hline W2F2 & $37.2^{\mathrm{bc}}$ & $72.5^{\mathrm{bcd}}$ & $103.5^{\mathrm{cd}}$ & $131.5^{\mathrm{ab}}$ & $30^{\mathrm{a}}$ & $74.1^{\mathrm{a}}$ & $87.2^{\mathrm{de}}$ & $110.4^{\mathrm{ab}}$ \\
\hline $\mathrm{W} 2 \mathrm{~F} 3$ & $34.3^{\mathrm{d}}$ & $68.3^{\mathrm{d}}$ & $100.5^{\mathrm{d}}$ & $127.7^{\mathrm{ab}}$ & $26.1^{\mathrm{b}}$ & $62^{\mathrm{cd}}$ & $86.2^{\mathrm{e}}$ & $110.2^{\mathrm{ab}}$ \\
\hline W3F1 & $38^{\mathrm{b}}$ & $73^{\mathrm{abcd}}$ & $113.5^{\mathrm{a}}$ & $135.1^{\mathrm{ab}}$ & $23.1^{b c}$ & $63.8^{\mathrm{bcd}}$ & $97.5^{\mathrm{ab}}$ & $113.3^{\mathrm{ab}}$ \\
\hline W3F2 & $35.5^{\mathrm{cd}}$ & $78^{\mathrm{a}}$ & $115^{\mathrm{a}}$ & $136.9^{\mathrm{ab}}$ & $24.6^{\mathrm{bc}}$ & $64.3^{\mathrm{bcd}}$ & $95.2^{\mathrm{abc}}$ & $113^{\mathrm{ab}}$ \\
\hline W3F3 & $34.1^{\mathrm{d}}$ & $73.8^{\mathrm{abc}}$ & $111^{\mathrm{ab}}$ & $132.1^{\mathrm{ab}}$ & $22.8^{\mathrm{c}}$ & $59.7^{\mathrm{d}}$ & $92.1^{\text {bcde }}$ & $107^{\mathrm{b}}$ \\
\hline \multicolumn{9}{|c|}{$p$ value of significance test } \\
\hline Irrigation & $* *$ & NS & $* * *$ & NS & $* * *$ & $* *$ & $*$ & NS \\
\hline Fertilizer & $* * *$ & * & NS & NS & * & * & * & NS \\
\hline Irrigation $\times$ fertilizer & $*$ & NS & * & NS & NS & NS & NS & NS \\
\hline
\end{tabular}

$\mathrm{D}$ is the days after transplanting and columns with the same letter represent values that are significant at the 5\% probability level. “***” means $p<0.001$, “**" means $0.001<p<0.01$, “*” means $0.01<p<0.05$, and "NS" means $p>0.05$.

The plant stem plays a very important role in plant anchorage and in the movement and transport of water, solutes, and nutrients. Importantly, the stem functions in photosynthesis and nutrient storage. The effects of irrigation and fertilizer on tomato stem diameter at the whole growth stages are shown in Table 2. At 23 days after transplanting, the highest stem diameter was $8.9 \mathrm{~mm}$ in 2012 and $6.8 \mathrm{~mm}$ in 2013 . The fertilizer treatment very significantly influenced the tomato stem diameter, irrigation $\times$ fertilizer significantly influenced the stem diameter, and irrigation treatment had no statistically significant effect in 2012. In 2013, the single factors of irrigation or fertilizer very significantly $(p<0.01)$ affected the stem diameter, but irrigation $\times$ fertilizer had no statistically significant effect. In addition, the rate of stem diameter increase decreased obviously at 37 days after transplanting, and the added values of stem diameter ranged from 0.9 to $2.2 \mathrm{~mm}$ at the blossoming and bearing fruits stage. The average stem diameter in F3 was significantly lower than that in the F1 and F2 treatments, and the fertilizer treatment very significantly influenced the tomato stem diameter. By 53 days after transplanting, the rate of stem diameter increase had undergone a steady decline, and the added value ranged from 0.6 to $1.1 \mathrm{~mm}$. The influence of stem diameter on fertilization was greater than that on irrigation throughout the entire stage.

The major function of leaves is to take in carbon dioxide for photosynthesis, the process of converting light energy into chemical energy. The effects of irrigation and fertilization on the leaf growth rate at the whole growth stages are shown in Figure 4 . The overall pattern of change in the leaf growth rate was represented by positive-negative and single-peak curves in both years. The single factors of irrigation or fertilizer very significantly affected the leaf expansion rate, but irrigation $x$ fertilizer had no statistically significant effect on the leaf growth rate at 23 days after transplanting. The highest leaf expansion rate was $4.5 \mathrm{~cm}^{2} \cdot \mathrm{leaf}^{-1} \cdot \mathrm{day}^{-1}$ at 23-37 days after 
TABLE 2: The effects of irrigation and fertilizer on stem diameter tomato ( $\mathrm{mm})$.

\begin{tabular}{|c|c|c|c|c|c|c|c|c|}
\hline \multirow{2}{*}{ Treatment } & \multicolumn{4}{|c|}{2012} & \multicolumn{4}{|c|}{2013} \\
\hline & $23 \mathrm{D}$ & $37 \mathrm{D}$ & $53 \mathrm{D}$ & $70 \mathrm{D}$ & $20 \mathrm{D}$ & $40 \mathrm{D}$ & $60 \mathrm{D}$ & $80 \mathrm{D}$ \\
\hline W1F1 & $8.46^{\mathrm{ab}}$ & $10.66^{\mathrm{a}}$ & $10.98^{\mathrm{a}}$ & $12.28^{\mathrm{ab}}$ & $7.85^{\mathrm{a}}$ & $8.74^{\mathrm{bc}}$ & $10.95^{\mathrm{ab}}$ & $12.18^{\mathrm{ab}}$ \\
\hline W1F2 & $7.66^{\mathrm{cd}}$ & $9.58^{\mathrm{bc}}$ & $10.1^{\mathrm{abc}}$ & $11.3^{\mathrm{bcd}}$ & $7.28^{\mathrm{b}}$ & $9.14^{\mathrm{ab}}$ & $11.68^{\mathrm{a}}$ & $12.88^{\mathrm{a}}$ \\
\hline W1F3 & $7.45^{\mathrm{d}}$ & $8.57^{\text {cde }}$ & $9.6^{\mathrm{bcd}}$ & $11.01^{\mathrm{cd}}$ & $6.84^{\mathrm{bc}}$ & $7.8^{\mathrm{d}}$ & $10.55^{\mathrm{ab}}$ & $11.26^{b c}$ \\
\hline $\mathrm{W} 2 \mathrm{~F} 1$ & $8.9^{\mathrm{a}}$ & $10.15^{\mathrm{ab}}$ & $10.74^{\mathrm{ab}}$ & $12.47^{\mathrm{a}}$ & $7.29^{b}$ & $8.89^{b c}$ & $9.91^{b c}$ & $11.33^{b c}$ \\
\hline $\mathrm{W} 2 \mathrm{~F} 2$ & $8.13^{b c d}$ & $9.16^{\text {bcde }}$ & $10.11^{\mathrm{abc}}$ & $11.6^{\mathrm{abc}}$ & $7.09^{b c}$ & $9.59^{\mathrm{a}}$ & $11.37^{\mathrm{a}}$ & $11.43^{b c}$ \\
\hline W2F3 & $6.49^{\mathrm{e}}$ & $8.44^{\mathrm{de}}$ & $9.26^{\mathrm{cd}}$ & $10.39^{\mathrm{d}}$ & $6.8^{\mathrm{bc}}$ & $7.37^{\mathrm{d}}$ & $9.01^{\mathrm{c}}$ & $10.45^{\mathrm{c}}$ \\
\hline W3F1 & $8.39^{\mathrm{abc}}$ & $9.33^{b c d}$ & $9.98^{\mathrm{abcd}}$ & $11.86^{\mathrm{abc}}$ & $6.62^{\mathrm{cd}}$ & $7.87^{\mathrm{d}}$ & $9.07^{\mathrm{c}}$ & $11.78^{\mathrm{b}}$ \\
\hline W3F2 & $8.03^{\mathrm{bcd}}$ & $8.93^{\text {cde }}$ & $9.53^{\mathrm{cd}}$ & $10.84^{\mathrm{cd}}$ & $6.24^{\mathrm{de}}$ & $8.44^{\mathrm{c}}$ & $9.43^{c}$ & $10.54^{\mathrm{c}}$ \\
\hline W3F3 & $5.94^{\mathrm{e}}$ & $8.21^{\mathrm{e}}$ & $8.91^{\mathrm{d}}$ & $10.29^{\mathrm{d}}$ & $5.96^{\mathrm{e}}$ & $6.65^{\mathrm{e}}$ & $7.93^{d}$ & $9.25^{\mathrm{d}}$ \\
\hline \multicolumn{9}{|c|}{$p$ value of significance test } \\
\hline Irrigation & NS & $*$ & NS & NS & $* * *$ & $* * *$ & $* * *$ & $* * *$ \\
\hline Fertilizer & $* * *$ & $* * *$ & $* *$ & $* * *$ & ** & $* * *$ & $* * *$ & $* * *$ \\
\hline Irrigation $\times$ fertilizer & $* *$ & NS & NS & NS & NS & NS & NS & NS \\
\hline
\end{tabular}

$\mathrm{D}$ is the days after transplanting and columns with the same letter represent values that are significant at the $5 \%$ probability level. “***” means $p<0.001$, “**" means $0.001<p<0.01$, “*” means $0.01<p<0.05$, and "NS" means $p>0.05$.

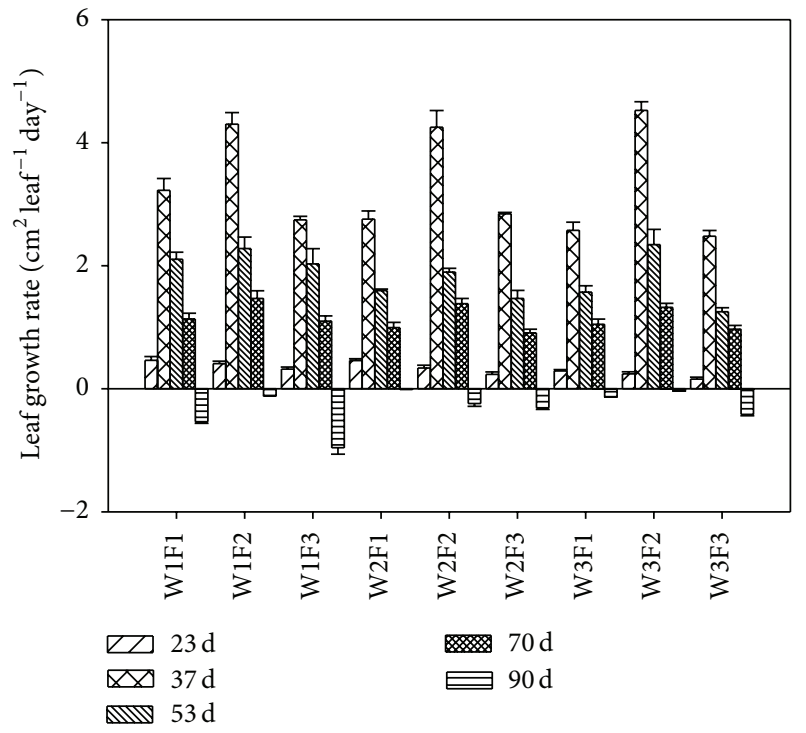

(a) 2012

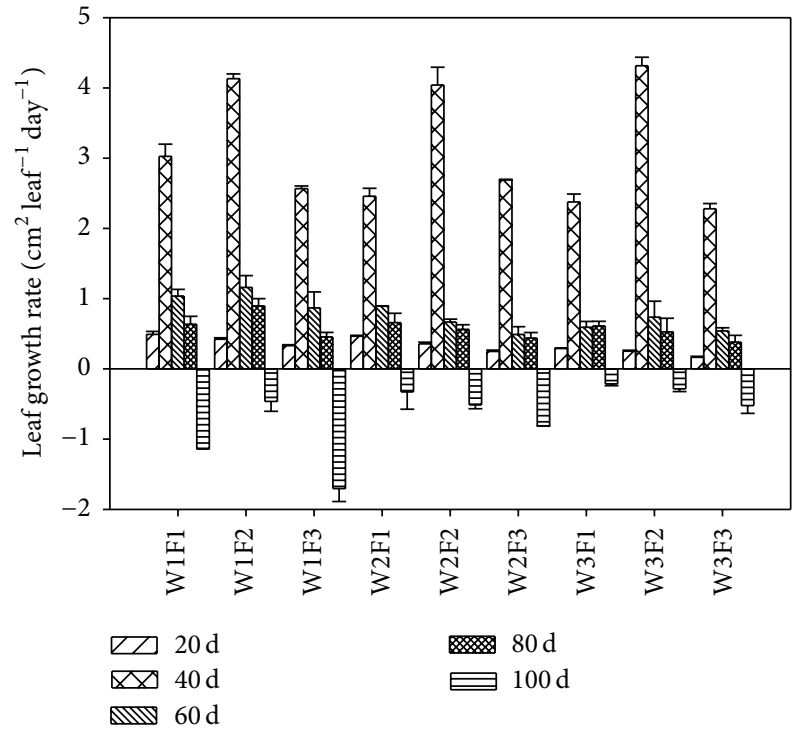

(b) 2013

Figure 4: The effects of irrigation and fertilizer on tomato leaf growth rate.

transplanting. The highest average leaf expansion rate was produced in the F2 treatment, and the fertilizer amount very significantly affected the leaf expansion rate in 2012. The leaf area continued to increase, but the rate of increase decreased in $37-53$ days after transplanting.

3.2. Dry Biomass Accumulation. The effects of irrigation and fertilizer on tomato dry biomass accumulation and the distribution in different organs are shown in Table 3. The highest dry biomass accumulation in the W1F1 treatment was $12 \mathrm{t} \cdot \mathrm{ha}^{-1}$, which was significantly higher than that in the other treatments; the fertilizer treatment significantly influenced dry biomass accumulation, but the irrigation treatment had no statistically significant effect in either year. The average root dry biomass in W1 (221.9 $\left.\mathrm{kg} \cdot \mathrm{ha}^{-1}\right)$ was $7 \%$ and $20.4 \%$ higher than that in the W2 and W3 treatments and the same as the stem and fruit dry biomass. There was no significant difference between the W1 and W2 treatments, and the average dry biomass accumulation in W1 was $6 \%$ and $6 \%$ higher than W2 in 2012 and 2013, respectively. With the same irrigation amount, the dry biomass accumulation in the F2 treatment was higher than that in the F1 and F3 treatments.

3.3. Tomato Yield. The interactions between irrigation and fertilizer treatments were important for tomato yield, and the single factors of irrigation or fertilizer very significantly $(p<0.01)$ affected the fruit yield in two consecutive years (Figure 5). The highest fruit yield was $96.7 \mathrm{t} \cdot \mathrm{ha}^{-1}$ in the W1F1 
TABLE 3: Effects of irrigation and fertilizer on tomato dry biomass accumulation and distribution in different organs.

\begin{tabular}{|c|c|c|c|c|c|c|c|c|c|c|}
\hline \multirow{2}{*}{ Year } & \multirow{2}{*}{ Treatment } & \multicolumn{5}{|c|}{ Dry biomass accumulation $\left(\mathrm{kg} \cdot \mathrm{hm}^{-2}\right)$} & \multicolumn{4}{|c|}{ Distribution in different organs (\%) } \\
\hline & & Fruit & Stem & Leaf & Root & Total & Fruit & Stem & Leaf & Root \\
\hline \multirow{9}{*}{2012} & W1F1 & $6219^{\mathrm{a}}$ & $2922^{\mathrm{a}}$ & $2635^{\mathrm{a}}$ & $247^{\mathrm{a}}$ & $12023^{\mathrm{a}}$ & $51.7^{\mathrm{bcd}}$ & $24.3^{\mathrm{ab}}$ & $21.9^{\mathrm{ab}}$ & $2.1^{\mathrm{a}}$ \\
\hline & $\mathrm{W} 1 \mathrm{~F} 2$ & $5828^{\mathrm{b}}$ & $2785^{\mathrm{ab}}$ & $2552^{\mathrm{a}}$ & $223^{\mathrm{b}}$ & $11389^{\mathrm{b}}$ & $51.2^{\mathrm{d}}$ & $24.4^{\mathrm{ab}}$ & $22.4^{\mathrm{ab}}$ & $2^{\mathrm{a}}$ \\
\hline & W1F3 & $5100^{\mathrm{d}}$ & $2660^{\mathrm{ab}}$ & $2172^{\mathrm{b}}$ & $195^{\mathrm{c}}$ & $10127^{\mathrm{c}}$ & $50.4^{\mathrm{d}}$ & $26.3^{\mathrm{a}}$ & $21.4^{\mathrm{bc}}$ & $1.9^{\mathrm{ab}}$ \\
\hline & W2F1 & $5615^{\mathrm{bc}}$ & $2504^{\mathrm{bc}}$ & $2573^{\mathrm{a}}$ & $230^{\mathrm{b}}$ & $10922^{\mathrm{b}}$ & $51.4^{\mathrm{cd}}$ & $22.9^{\mathrm{bc}}$ & $23.6^{\mathrm{a}}$ & $2.1^{\mathrm{a}}$ \\
\hline & $\mathrm{W} 2 \mathrm{~F} 2$ & $5475^{\mathrm{c}}$ & $2221^{\mathrm{cd}}$ & $2309^{b}$ & $215^{\mathrm{b}}$ & $10221^{\mathrm{c}}$ & $53.6^{\mathrm{bc}}$ & $21.7^{\mathrm{c}}$ & $22.6^{\mathrm{ab}}$ & $2.1^{\mathrm{a}}$ \\
\hline & $\mathrm{W} 2 \mathrm{~F} 3$ & $5030 \mathrm{~d}^{\mathrm{e}}$ & $1993^{\mathrm{de}}$ & $1720^{c}$ & $174^{\mathrm{d}}$ & $8917^{\mathrm{e}}$ & $56.4^{\mathrm{a}}$ & $22.3^{\mathrm{bc}}$ & $19.3^{\mathrm{de}}$ & $2^{\mathrm{a}}$ \\
\hline & $\mathrm{W} 3 \mathrm{~F} 1$ & $5119^{\mathrm{d}}$ & $2231^{\mathrm{cd}}$ & $2247^{\mathrm{b}}$ & $197^{\mathrm{c}}$ & $9794^{\text {cd }}$ & $52.3^{\mathrm{bcd}}$ & $22.8^{\mathrm{bc}}$ & $23^{\mathrm{ab}}$ & $2^{\mathrm{a}}$ \\
\hline & W3F2 & $4984^{\mathrm{de}}$ & $2221^{\mathrm{cd}}$ & $1849^{c}$ & $194^{\mathrm{c}}$ & $9247^{\mathrm{de}}$ & $53.9^{\mathrm{b}}$ & $24^{\mathrm{abc}}$ & $20^{\mathrm{cd}}$ & $2.1^{\mathrm{a}}$ \\
\hline & W3F3 & $4722^{\mathrm{e}}$ & $1876^{\mathrm{e}}$ & $1460^{\mathrm{d}}$ & $140^{\mathrm{e}}$ & $8198^{\mathrm{f}}$ & $57.6^{\mathrm{a}}$ & $22.9^{\mathrm{bc}}$ & $17.8^{\mathrm{e}}$ & $1.7^{\mathrm{b}}$ \\
\hline \multicolumn{11}{|c|}{$p$ value of significance test } \\
\hline & Irrigation & $* *$ & * & $*$ & $* *$ & $* *$ & $* *$ & $*$ & $*$ & $* *$ \\
\hline & Fertilizer & $* * *$ & NS & * & * & * & $* * *$ & NS & $*$ & * \\
\hline \multicolumn{2}{|c|}{ Irrigation $\times$ fertilizer } & $* * *$ & NS & * & NS & NS & $* * *$ & NS & * & NS \\
\hline \multirow{9}{*}{2013} & W1F1 & $5100^{\mathrm{a}}$ & $1818^{\mathrm{c}}$ & $1973^{\mathrm{a}}$ & $254^{\mathrm{c}}$ & $9145^{\mathrm{a}}$ & $55.8^{\mathrm{abc}}$ & $19.9^{\mathrm{d}}$ & $21.6^{\mathrm{bcd}}$ & $2.8^{\mathrm{b}}$ \\
\hline & W1F2 & $4781^{\mathrm{ab}}$ & $2106^{\mathrm{a}}$ & $2031^{\mathrm{a}}$ & $330^{\mathrm{a}}$ & $9248^{\mathrm{a}}$ & $51.7^{\mathrm{c}}$ & $22.8^{\mathrm{abc}}$ & $22^{\mathrm{bc}}$ & $3.6^{\mathrm{a}}$ \\
\hline & W1F3 & $4090^{\mathrm{bc}}$ & $1663^{\mathrm{d}}$ & $1965^{\mathrm{a}}$ & $209^{\mathrm{d}}$ & $7927^{\mathrm{bc}}$ & $51.5^{\mathrm{c}}$ & $21^{\mathrm{bcd}}$ & $24.8^{\mathrm{a}}$ & $2.6^{\mathrm{b}}$ \\
\hline & $\mathrm{W} 2 \mathrm{~F} 1$ & $4461^{\mathrm{abc}}$ & $1477^{\mathrm{e}}$ & $1757^{\mathrm{b}}$ & $217^{\mathrm{d}}$ & $7913^{\mathrm{bc}}$ & $56.3^{\mathrm{ab}}$ & $18.7^{\mathrm{d}}$ & $22.2^{\mathrm{b}}$ & $2.7^{\mathrm{b}}$ \\
\hline & $\mathrm{W} 2 \mathrm{~F} 2$ & $4300^{\mathrm{bc}}$ & $1960^{\mathrm{b}}$ & $1809^{\mathrm{b}}$ & $306^{\mathrm{b}}$ & $8375^{\mathrm{b}}$ & $51.3^{c}$ & $23.4^{\mathrm{ab}}$ & $21.6^{\mathrm{bcd}}$ & $3.7^{\mathrm{a}}$ \\
\hline & $\mathrm{W} 2 \mathrm{~F} 3$ & $3707^{\mathrm{c}}$ & $1772^{\mathrm{cd}}$ & $1394^{\mathrm{d}}$ & $193^{\mathrm{d}}$ & $7066^{\mathrm{d}}$ & $52.4^{\mathrm{bc}}$ & $25.1^{\mathrm{a}}$ & $19.7^{\mathrm{d}}$ & $2.7^{\mathrm{b}}$ \\
\hline & W3F1 & $4087^{\mathrm{bc}}$ & $1692^{\mathrm{d}}$ & $1498^{\mathrm{cd}}$ & $197^{\mathrm{d}}$ & $7473^{\mathrm{cd}}$ & $54.6^{\mathrm{bc}}$ & $22.7^{\mathrm{abc}}$ & $20.1^{\mathrm{cd}}$ & $2.6^{\mathrm{b}}$ \\
\hline & W3F2 & $3945^{c}$ & $1502^{\mathrm{e}}$ & $1607^{\mathrm{c}}$ & $151^{\mathrm{e}}$ & $7206^{\mathrm{cd}}$ & $54.7^{\mathrm{bc}}$ & $20.9^{\mathrm{cd}}$ & $22.3^{\mathrm{b}}$ & $2.1^{\mathrm{c}}$ \\
\hline & W3F3 & $3740^{\mathrm{c}}$ & $1168^{\mathrm{f}}$ & $1243^{\mathrm{e}}$ & $139^{\mathrm{e}}$ & $6290^{\mathrm{e}}$ & $59.4^{\mathrm{a}}$ & $18.6^{\mathrm{d}}$ & $19.8^{\mathrm{d}}$ & $2.2^{\mathrm{c}}$ \\
\hline \multicolumn{11}{|c|}{$p$ value of significance test } \\
\hline & Irrigation & $* * *$ & * & * & $* *$ & $* *$ & $* * *$ & * & * & $* *$ \\
\hline & Fertilizer & $* * *$ & NS & * & * & * & $* * *$ & NS & * & * \\
\hline Irriga & tion $\times$ fertilizer & $* * *$ & NS & * & NS & NS & $* * *$ & NS & $*$ & NS \\
\hline
\end{tabular}

treatment, which was $9.7 \%$ and $17.7 \%$ higher than that in $\mathrm{W} 2 \mathrm{~F} 1$ and $\mathrm{W} 3 \mathrm{~F} 1$ in 2012 . The same result was produced in 2013, and the highest fruit yield was $97.1 \mathrm{t} \cdot \mathrm{ha}^{-1}$ in the W1F1 treatment, which was $12.5 \%$ and $19.9 \%$ higher than that in $\mathrm{W} 2 \mathrm{~F} 1$ and $\mathrm{W} 3 \mathrm{~F} 1$. In both years, the results indicated that the increased irrigation level and fertilizer rate increased the fruit yield of tomatoes. The mean fruit yield of the $\mathrm{W} 1$ treatment was $88.9 \mathrm{t} \cdot \mathrm{ha}^{-1}$ in 2012 , which was $6 \%$ and $13.5 \%$ higher than that in $\mathrm{W} 2$ and $\mathrm{W} 3$. The mean fruit yield in the F1 treatment was $87.9 \mathrm{t} \cdot \mathrm{ha}^{-1}$ in 2012 , which was $3.9 \%$ and $12.4 \%$ higher than that in F2 and F3. The results indicated that fruit yield had a slightly higher sensitivity to treatment with irrigation than to that with fertilization.

3.4. Water Use Efficiency. The effects of irrigation and fertilizer on the WUE are shown in Figure 6. The irrigation treatment significantly affected the WUE. The results showed a significant negative correlation between WUE and irrigation amount. The highest WUE was obtained in the W3F1 treatment and was $45 \mathrm{~kg} \cdot \mathrm{m}^{-3}$ and $47.7 \mathrm{~kg} \cdot \mathrm{m}^{-3}$ in 2012 and 2013 , respectively. When the irrigation amount decreased, the WUE increased. The average WUE in the W3 treatment was $27.3 \%$ and $18.7 \%$ higher than that in the $\mathrm{W} 1$ and $\mathrm{W} 2$ treatments in 2012, and the same result was observed in 2013. There was a positive correlation between the WUE and fertilizer amount; the average WUE in the F3 treatments was $14.8 \%$ and $10.7 \%$ higher than that in the F1 and F2 treatments in 2012. The results indicated that the WUE was more sensitive to irrigation than fertilizer.

3.5. Recommended Levels of Irrigation and Fertilization. The regression model was used to predict the effect of an unknown dependent variable on the fruit yield and WUE, given the values of the independent variables of irrigation amount and fertilizer level. The fertilizer and irrigation supply affected the fruit yield and WUE, with a very significant interaction between them in both years. In the two successive growing seasons, the extreme calculation results showed that the fruit yield peaked at the maximal irrigation amount, while the WUE peaked at the minimal irrigation amount. 


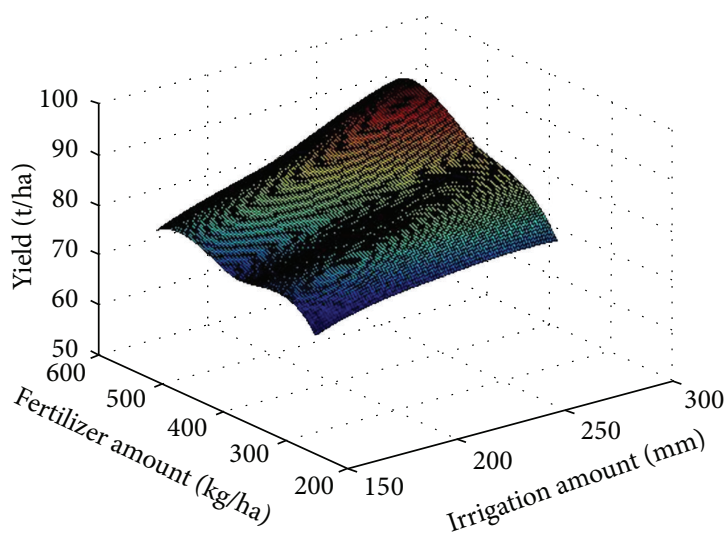

(a) 2012

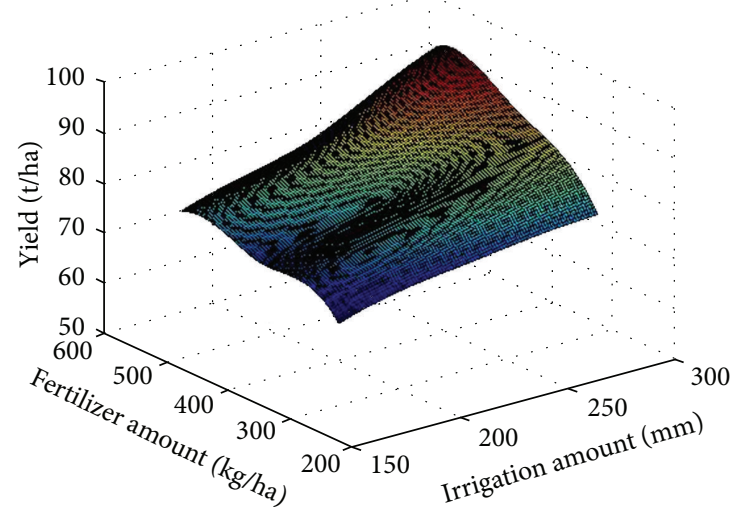

(b) 2013

FIGURE 5: The effects of irrigation and fertilizer on tomato fruit yield in 2012 and 2013.

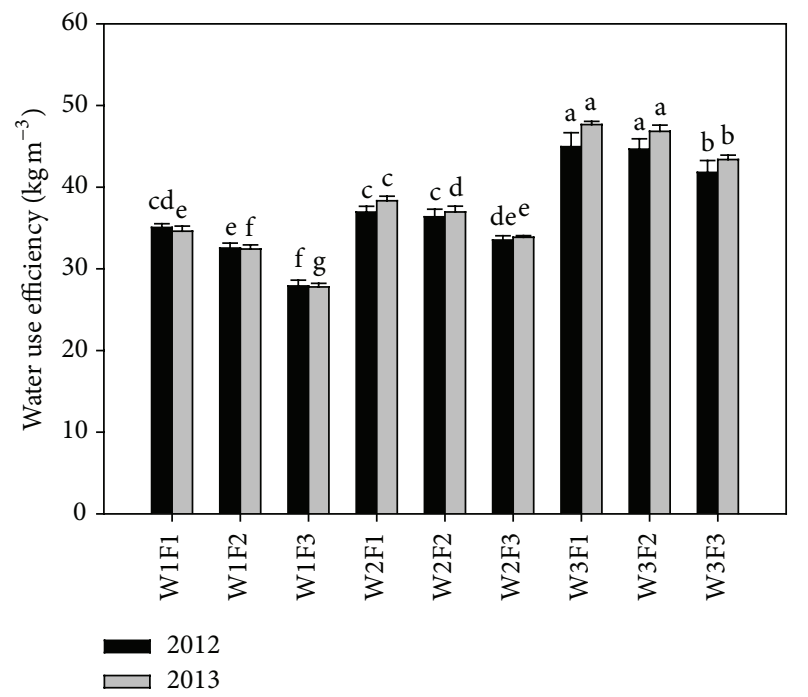

FIgURE 6: The effects of irrigation and fertilizer on water use efficiency in 2012 and 2013; the same letter represents values that are significant at the $5 \%$ probability level.

Therefore, the tomato yield and WUE cannot simultaneously reach their maxima.

When the WUE was maximal, irrigation was minimal, and the fertilizer amount was close to maximal. Therefore, it is necessary to perform further studies on the input of irrigation and fertilizer, which affect fruit yield and WUE.

In our study, a multiple regression analysis was used to develop a hypothesis in which fruit yield and WUE were equally important $\left(\lambda_{1}=\lambda_{2}=0.5\right)$. The relationships among irrigation, fertilizer, and the weighted fruit yield and WUE were determined using the following equations:

$$
\begin{aligned}
2012: Y= & 1.18-4.83 \times 10^{-3} W+7.62 \times 10^{-4} F+6.80 \\
& \times 10^{-6} W^{2}-1.42 \times 10^{-6} F^{2}+3.62 \\
& \times 10^{-6} W F
\end{aligned}
$$

$$
\text { 2013: } \begin{aligned}
Y= & 1.33-7.11 \times 10^{-3} \mathrm{~W}+1.18 \times 10^{-3} \mathrm{~F}+1.21 \\
& \times 10^{-5} W^{2}-1.75 \times 10^{-6} F^{2}+3.02 \\
& \times 10^{-6} W F
\end{aligned}
$$

where $Y$ is the optimization value considering the fruit yield and WUE $\left(\mathrm{t} \cdot \mathrm{ha}^{-1}\right), W$ is the irrigation amount $(\mathrm{mm})$, and $F$ is the fertilizer amount $\left(\mathrm{kg} \cdot \mathrm{ha}^{-1}\right)$.

The optimal value of the target function was calculated by MATLAB. The irrigation amount and fertilizer amount were $151 \mathrm{~mm}$ and $453.6 \mathrm{~kg} \cdot \mathrm{ha}^{-1}$ (nitrogen, phosphorus, and potassium fertilizers were $213.5,106.7$, and $133.4 \mathrm{~kg} \cdot \mathrm{ha}^{-1}$, resp.) in 2012, respectively. The irrigation amount and fertilizer amount were $207.8 \mathrm{~mm}$ and $461.08 \mathrm{~kg} \cdot \mathrm{ha}^{-1}$ (nitrogen, phosphorus, and potassic fertilizers were 217, 108, and $135.6 \mathrm{~kg} \cdot \mathrm{ha}^{-1}$, resp.) in 2013 , respectively.

\section{Discussion}

The relationships between the growth indexes and the irrigation amount and fertilizer level were statistically analyzed, and the positive correlation was significant. In two consecutive years, the plant height and leaf growth rate were higher in W2F1 than in the other treatments at 23 days after transplanting, which may be due to water consumption. The results were the same as those of Zhu et al. [35], who reported that higher levels of irrigation can inhibit plant height increase. It is of great importance to study the growth and soil water required for tomato dry matter accumulation under irrigation and fertilization strategies with drip irrigation, as too much water can cause excessive vegetative growth; the most important thing is the proper proportion of irrigation and fertilizer [36]. There was a positive correlation between dry matter accumulation and fertilizer amount, and fertilizer treatment was more sensitive to dry matter accumulation than irrigation treatment. During the growth period, the leaf growth rate increased rapidly at first, and then the rate of 
increase decreased and the growth plateaued. There was no significant difference between the irrigation treatment and leaf growth rate, and the same result was obtained as with dry matter accumulation. Crop evapotranspiration is closely related to crop growth and water consumption during crop growth, which is irreversible. The result was same as that of Wang et al. [37], the tomato dry matter accumulation was mainly due to irrigation and fertilization, and there was no significant difference in the dry matter accumulation at the whole growth stage. Fertilization was more sensitive to fruit yield than irrigation and the irrigation treatment was more sensitive than the interaction between irrigation and fertilization [38].

The results showed that irrigation and fertilization had significant effects on tomato yield, and the effects of the interaction between irrigation and fertilizer were very significant. The same results were obtained in greenhouse that there was a significant difference in the tomato yield in the irrigation and fertilization treatments, due to irrigation, fertilizer, and the interaction between the two factors [39]. However, in this experiment, the interaction between irrigation and fertilization was more sensitive than the single factors of fertilization or irrigation; the reason for this result may be that the effect of the interaction between water and fertilizer was obvious and could be used in further studies on the effect of the interaction between irrigation and fertilization on tomato growth.

The results showed that different irrigation and fertilization supplies significantly affected the WUE and that the effect of irrigation treatment on the WUE was significant. The influence of the interaction between irrigation and fertilization on the WUE was not significant; however, the effect of irrigation treatment on the WUE was greater than the effect of fertilization. Javanmardi and Kubota [40] and Maria do Rosário et al. [41] reported that fertilizer improved the WUE; under the same irrigation level, fertilization could effectively improve the WUE. This result is consistent with our experimental results. There are two reasons explaining why fertilization improved the WUE. One reason might be that fertilization can promote tomato root growth and development, thereby improving the root system's capacity to absorb water and nutrients [42]. Another reason may be that tomato water consumption improved during growth, causing the roots near soil water movement to increase the efficiency of soil water absorption and to further improve the WUE of the soil.

\section{Conclusions}

Generally, it is difficult to obtain the maximal WUE and the maximum yield simultaneously. Reducing the amount of irrigation water will result in higher WUE; based on this characteristic, the highest WUE and fruit yield cannot occur at the same time. According to this characteristic, tomatoes require fertilizer and water at the same time. The tomato yield and WUE are equally important and the tomato yield and WUE coefficients are each 0.5. An irrigation amount of 151.1 to $207.8 \mathrm{~mm}$ and a fertilizer amount of 453.6 to $461.1 \mathrm{~kg} \cdot \mathrm{ha}^{-1}$ for greenhouse tomato surface drip fertigation are recommended (nitrogen fertilizer, 213.5-217 kg.ha ${ }^{-1}$; phosphate fertilizer, 106.7-108 $\mathrm{kg} \cdot \mathrm{ha}^{-1}$; and potassium fertilizer, 133.4$\left.135.6 \mathrm{~kg} \cdot \mathrm{ha}^{-1}\right)$.

\section{Competing Interests}

The authors declare that there is no conflict of interests regarding the publication of this paper.

\section{Acknowledgments}

This research was supported by Specialized Research Fund for the Doctoral Program of Yanan University (205040119, 205040123), Shaanxi Province High-Level University Construction Special Fund Projects of Ecology (2012SXTC03), and Special Scientific Research Project in Shaanxi Province Department of Education (16JK1853).

\section{References}

[1] S. Phuntsho, H. K. Shon, S. Hong, S. Lee, and S. Vigneswaran, "A novel low energy fertilizer driven forward osmosis desalination for direct fertigation: evaluating the performance of fertilizer draw solutions," Journal of Membrane Science, vol. 375, no. 1-2, pp. 172-181, 2011.

[2] J. Hagin and A. Lowengart, "Fertigation for minimizing environmental pollution by fertilizers," Fertilizer Research, vol. 43, no. 1-3, pp. 5-7, 1996.

[3] T. A. Howell, "Enhancing water use efficiency in irrigated agriculture," Agronomy Journal, vol. 93, no. 2, pp. 281-289, 2001.

[4] J. Li, J. Zhang, and L. Ren, "Water and nitrogen distribution as affected by fertigation of ammonium nitrate from a point source," Irrigation Science, vol. 22, no. 1, pp. 19-30, 2003.

[5] S. S. Hebbar, B. K. Ramachandrappa, H. V. Nanjappa, and M. Prabhakar, "Studies on NPK drip fertigation in field grown tomato (Lycopersicon esculentum Mill.)," European Journal of Agronomy, vol. 21, no. 1, pp. 117-127, 2004.

[6] Z. Hou, P. Li, B. Li, J. Gong, and Y. Wang, "Effects of fertigation scheme on N uptake and N use efficiency in cotton," Plant and Soil, vol. 290, no. 1-2, pp. 115-126, 2007.

[7] K. O. Burkey, F. L. Booker, W. A. Pursley, and A. S. Heagle, "Elevated carbon dioxide and ozone effects on peanut: II. Seed yield and quality," Crop Science, vol. 47, no. 4, pp. 1488-1497, 2007.

[8] E. Baldi, G. Marcolini, M. Quartieri, G. Sorrenti, and M. Toselli, "Effect of organic fertilization on nutrient concentration and accumulation in nectarine (Prunus persica var. nucipersica) trees: the effect of rate of application," Scientia Horticulturae, vol. 179, pp. 174-179, 2014.

[9] G. Evgenidis, E. Traka-Mavrona, and M. Koutsika-Sotiriou, "Principal component and cluster analysis as a tool in the assessment of tomato hybrids and cultivars," International Journal of Agronomy, vol. 2011, Article ID 697879, 7 pages, 2011.

[10] I. K. Arah, H. Amaglo, E. K. Kumah, and H. Ofori, "Preharvest and postharvest factors affecting the quality and shelf life of harvested tomatoes: a mini review," International Journal of Agronomy, vol. 2015, Article ID 478041, 6 pages, 2015.

[11] W. You and A. V. Barker, "Effects of soil-applied glufosinateammonium on tomato plant growth and ammonium accumulation," Communications in Soil Science and Plant Analysis, vol. 35, no. 13-14, pp. 1945-1955, 2004. 
[12] S. De Pascale, A. Maggio, V. Fogliano, P. Ambrosino, and A. Ritieni, "Irrigation with saline water improves carotenoids content and antioxidant activity of tomato," The Journal of Horticultural Science and Biotechnology, vol. 76, no. 4, pp. 447453, 2001.

[13] G. Farré, G. Sanahuja, S. Naqvi et al., "Travel advice on the road to carotenoids in plants," Plant Science, vol. 179, no. 1-2, pp. 2848, 2010.

[14] H. Zhao, Y.-C. Xiong, F.-M. Li et al., "Plastic film mulch for half growing-season maximized WUE and yield of potato via moisture-temperature improvement in a semi-arid agroecosystem," Agricultural Water Management, vol. 104, pp. 68-78, 2012.

[15] G. Mahajan and K. G. Singh, "Response of Greenhouse tomato to irrigation and fertigation," Agricultural Water Management, vol. 84, no. 1-2, pp. 202-206, 2006.

[16] F. Favati, S. Lovelli, F. Galgano, V. Miccolis, T. Di Tommaso, and V. Candido, "Processing tomato quality as affected by irrigation scheduling," Scientia Horticulturae, vol. 122, no. 4, pp. 562-571, 2009.

[17] J. P. Mitchell, C. Shennan, S. R. Grattan, and D. M. May, "Tomato fruit yields and quality under water deficit and salinity," Journal of the American Society for Horticultural Science, vol. 116, no. 2, pp. 215-221, 1991.

[18] V. Dewanto, X. Wu, K. K. Adom, and R. H. Liu, “Thermal processing enhances the nutritional value of tomatoes by increasing total antioxidant activity," Journal of Agricultural and Food Chemistry, vol. 50, no. 10, pp. 3010-3014, 2002.

[19] H. Gulen and A. Eris, "Effect of heat stress on peroxidase activity and total protein content in strawberry plants," Plant Science, vol. 166, no. 3, pp. 739-744, 2004.

[20] K. Liu, T. Q. Zhang, C. S. Tan, and T. Astatkie, "Responses of fruit yield and quality of processing tomato to drip-irrigation and fertilizers phosphorus and potassium," Agronomy Journal, vol. 103, no. 5, pp. 1339-1345, 2011.

[21] A. S. Isah, E. B. Amans, E. C. Odion, and A. A. Yusuf, "Growth rate and yield of two tomato varieties (Lycopersicon esculentum mill) under green manure and NPK fertilizer rate Samaru northern guinea savanna," International Journal of Agronomy, vol. 2014, Article ID 932759, 8 pages, 2014.

[22] K. Liu, T. Q. Zhang, and C. S. Tan, "Processing tomato phosphorus utilization and post-harvest soil profile phosphorus as affected by phosphorus and potassium additions and drip irrigation," Canadian Journal of Soil Science, vol. 91, no. 3, pp. 417-425, 2011.

[23] T. Q. Zhang, C. S. Tan, K. Liu, C. F. Drury, A. P. Papadopoulos, and J. Warner, "Yield and economic assessments of fertilizer nitrogen and phosphorus for processing tomato with drip fertigation," Agronomy Journal, vol. 102, no. 2, pp. 774-780, 2010.

[24] H. Kuşçu, A. Turhan, and A. O. Demir, "The response of processing tomato to deficit irrigation at various phenological stages in a sub-humid environment," Agricultural Water Management, vol. 133, pp. 92-103, 2014.

[25] F. He, Q. Chen, R. Jiang, X. Chen, and F. Zhang, "Yield and nitrogen balance of greenhouse tomato (Lycopersicum esculentum Mill.) with conventional and site-specific nitrogen management in Northern China," Nutrient Cycling in Agroecosystems, vol. 77, no. 1, pp. 1-14, 2007.

[26] J. Chen, S. Kang, T. Du, R. Qiu, P. Guo, and R. Chen, "Quantitative response of greenhouse tomato yield and quality to water deficit at different growth stages," Agricultural Water Management, vol. 129, pp. 152-162, 2013.
[27] J. Zheng, G. Huang, D. Jia et al., "Responses of drip irrigated tomato (Solanum lycopersicum L.) yield, quality and water productivity to various soil matric potential thresholds in an arid region of Northwest China," Agricultural Water Management, vol. 129, pp. 181-193, 2013.

[28] C. Patanè and S. L. Cosentino, "Effects of soil water deficit on yield and quality of processing tomato under a Mediterranean climate," Agricultural Water Management, vol. 97, no. 1, pp. 131138,2010

[29] M. T. Castellanos, M. J. Cabello, M. C. Cartagena, A. M. Tarquis, A. Arce, and F. Ribas, "Nitrogen uptake dynamics, yield and quality as influenced by nitrogen fertilization in 'Piel de sapo' melon," Spanish Journal of Agricultural Research, vol. 10, no. 3, pp. 756-767, 2012.

[30] R. Qiu, J. Song, T. Du et al., "Response of evapotranspiration and yield to planting density of solar greenhouse grown tomato in northwest China," Agricultural Water Management, vol. 130, pp. 44-51, 2013.

[31] M. D. Fernández, S. Bonachela, F. Orgaz et al., "Erratum to: measurement and estimation of plastic greenhouse reference evapotranspiration in a Mediterranean climate," Irrigation Science, vol. 29, no. 1, pp. 91-92, 2011.

[32] R. G. Allen, L. S. Pereira, D. Raes, and M. Smith, Crop Evapotranspiration-Guide-lines for Computing Crop Water Requirements, FAO Irrigation and drainage paper no. 56, FAO, Rome, Italy, 1998.

[33] Z. Wang, Z. Liu, Z. Zhang, and X. Liu, "Subsurface drip irrigation scheduling for cucumber (Cucumis sativus L.) grown in solar greenhouse based on $20 \mathrm{~cm}$ standard pan evaporation in Northeast China," Scientia Horticulturae, vol. 123, no. 1, pp. 51-57, 2009.

[34] F. Wang, S. Kang, T. Du, F. Li, and R. Qiu, "Determination of comprehensive quality index for tomato and its response to different irrigation treatments," Agricultural Water Management, vol. 98, no. 8, pp. 1228-1238, 2011.

[35] G.-L. Zhu, Y.-Y. Hu, and Q.-R. Wang, "Nitrogen removal performance of anaerobic ammonia oxidation co-culture immobilized in different gel carriers," Water Science \& Technology, vol. 59, no. 12, pp. 2379-2386, 2009.

[36] W. Xiukang, L. Zhanbin, and X. Yingying, "Effects of mulching and nitrogen on soil temperature, water content, nitrate- $\mathrm{N}$ content and maize yield in the Loess Plateau of China," Agricultural Water Management, vol. 161, pp. 53-64, 2015.

[37] C. Wang, W. Liu, Q. Li et al., "Effects of different irrigation and nitrogen regimes on root growth and its correlation with above-ground plant parts in high-yielding wheat under field conditions," Field Crops Research, vol. 165, pp. 138-149, 2014.

[38] R. B. Singandhupe, G. G. S. N. Rao, N. G. Patil, and P. S. Brahmanand, "Fertigation studies and irrigation scheduling in drip irrigation system in tomato crop (Lycopersicon esculentum L.)," European Journal of Agronomy, vol. 19, no. 2, pp. 327-340, 2003.

[39] A. Ozbahce and A. F. Tari, "Effects of different emitter space and water stress on yield and quality of processing tomato under semi-arid climate conditions," Agricultural Water Management, vol. 97, no. 9, pp. 1405-1410, 2010.

[40] J. Javanmardi and C. Kubota, "Variation of lycopene, antioxidant activity, total soluble solids and weight loss of tomato during postharvest storage," Postharvest Biology and Technology, vol. 41, no. 2, pp. 151-155, 2006. 
[41] G. O. Maria do Rosário, A. M. Calado, and C. A. M. Portas, "Tomato root distribution under drip irrigation," Journal of the American Society for Horticultural science, vol. 121, no. 4, pp. 644-648, 1996.

[42] A. M. K. Nassar, S. Kubow, and D. J. Donnelly, "Highthroughput screening of sensory and nutritional characteristics for cultivar selection in commercial hydroponic greenhouse crop production," International Journal of Agronomy, vol. 2015, Article ID 376417, 28 pages, 2015. 


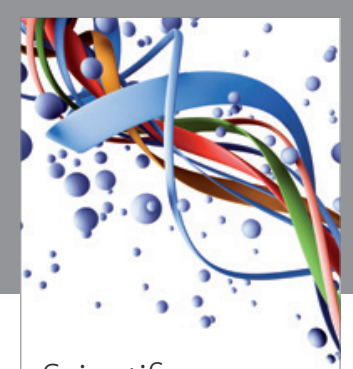

Scientifica
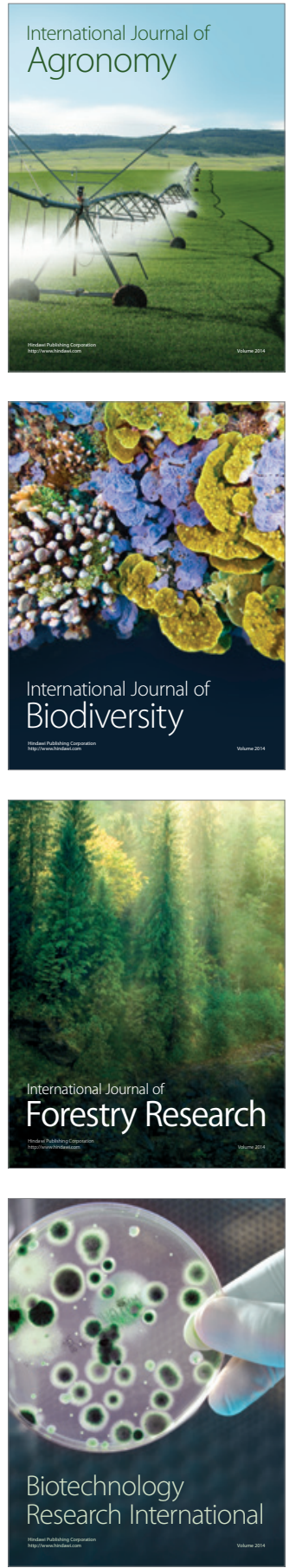
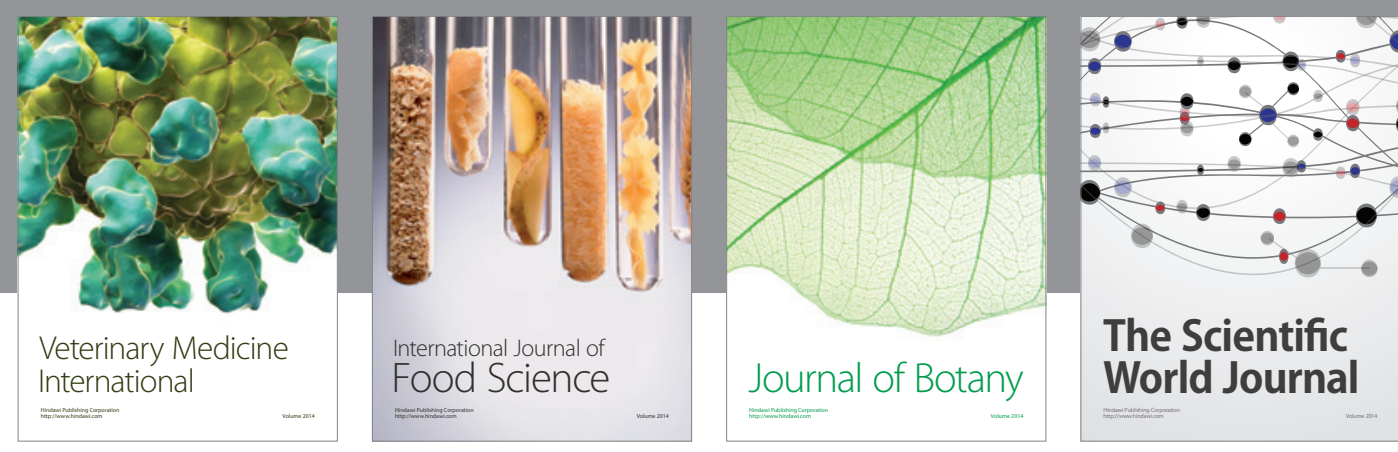

The Scientific

\section{World Journal}

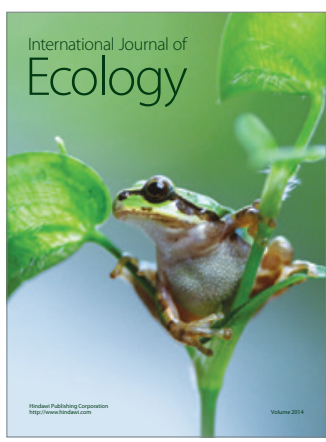

\section{Hindawi}

Submit your manuscripts at

http://www.hindawi.com
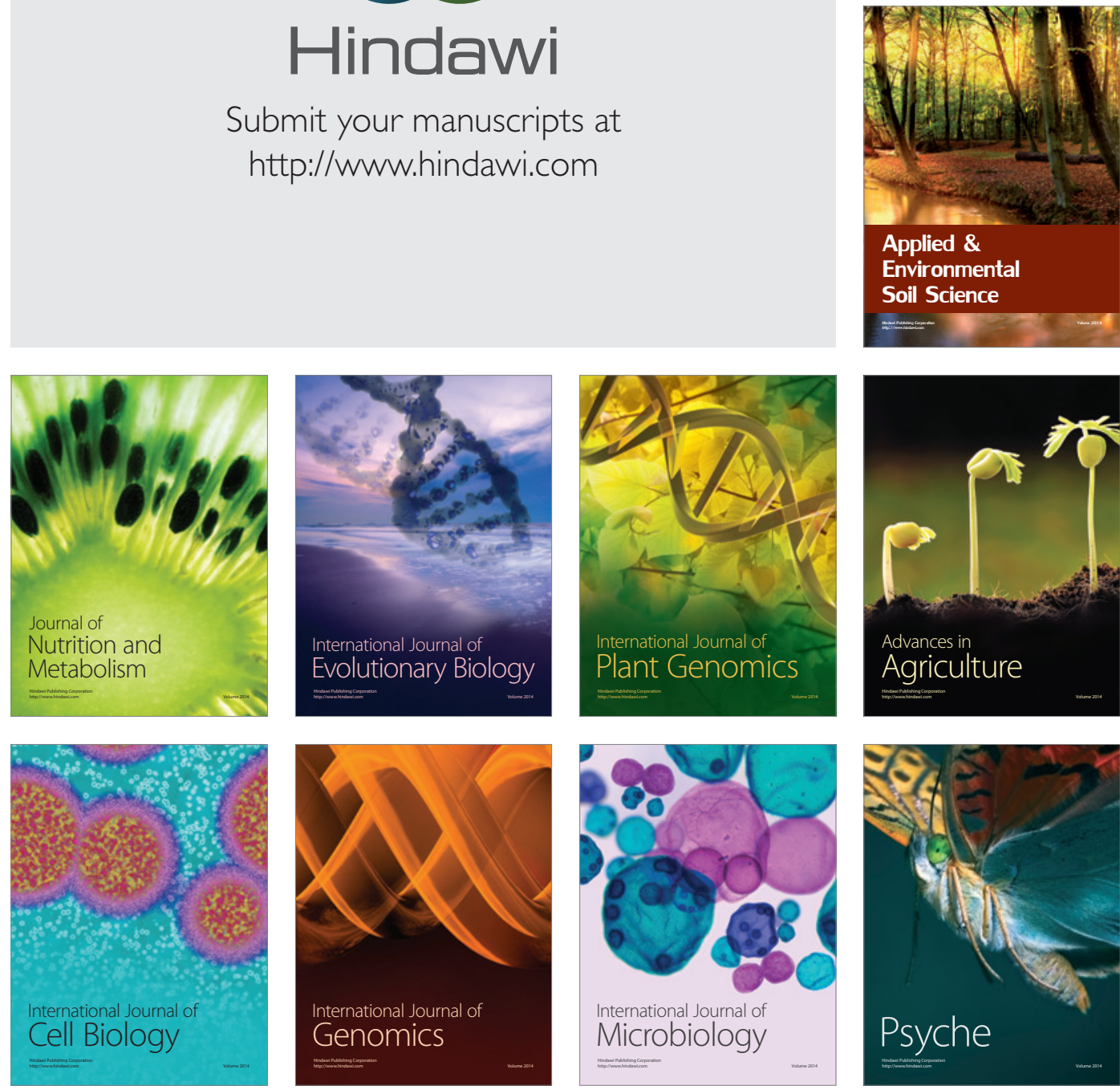
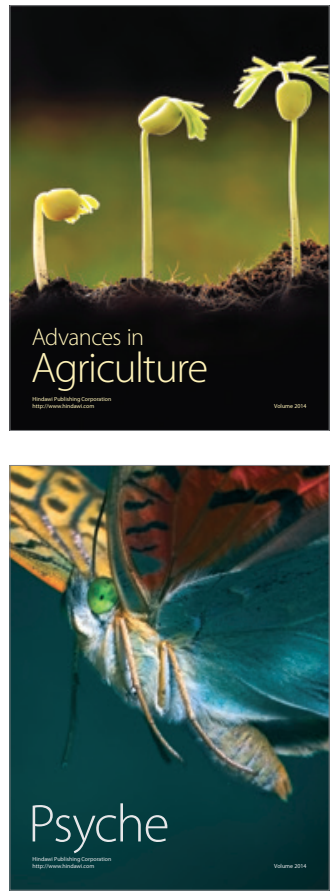